\title{
NAFTA: A CONCISE USER'S GUIDE TO THE NORTH AMERICAN FREE TRADE AGREEMENT by Barry Appleton (Scarborough: Carswell, 1994).
}

Novigating NAFTA,' by Barry Appleton, attempts to provide a "concise, unbiased and accurate account of what is contained in the NAFTA." ${ }^{2}$ The author states at the outset that his intent is to make the North American Free Trade Agreement (NAFTA) ${ }^{3}$ "more accessible," rather than to focus on the "political, philosophical, economic or social impact of the Agreement." I, however, would have liked to have seen more reference made to these issues as it would have put the Agreement in context.

Any text which attempts to make the Agreement more accessible is welcome. In particular, there is little legal literature as yet pertaining to the Agreement from a Canadian perspective. This book can be read fairly quickly, and it gives a good overview of the text of the Agreement. It is rather like the "Coles Notes" to the NAFTA. For a legal problem of any complexity, one would need to reference the text of the Agreement itself and decisions of the arbitral tribunals created under article 1131 of the Agreement. ${ }^{6}$ There is no discussion of dispute settlement panel decisions, presumably as these were not yet in existence at the time of publication.

The author approaches the Agreement and the Side Agreements on Labour and the Environment ${ }^{7}$ chapter-by-chapter. He arranges the text in the order in which subjects are addressed in the Agreement and makes reference to other Agreements which are germane where needed. For example, Appleton gives instances where aspects of the NAFTA differ from the Canada-U.S. Free Trade Agreement ${ }^{8}$ and makes reference to NAFTA provisions that are consistent with the obligations of Canada and the United States under The General Agreement on Tariffs and Trade. ${ }^{9}$

I would like to thank my colleague Leon Trakman for his comments on an earlier draft of this review. The views stated herein are those of the writer and do not purport to be those of the Court of Appeal. This review is written in a personal capacity, not an official capacity.

1 B. Appleton, Navigating NAFTA: A Concise User's Guide to The North American Free Trade Agreement (Scarborough: Carswell, 1994).

2 Appleton, ibid. at 1.

3 Government of Canada, North American Agreement on Labor Cooperation Between the Government of Canada, the Government of the United Mexican States and the Government of the United States of America. Final draft September 13, 1993. (Ottawa: Government of Canada, 1993).

- Appleton, supra note 1 at 2.

Ibid.

Appleton discusses arbitral awards at ibid., 145-55.

There are two agreements that were entered into in September, 1993 and which came into effect on January 1, 1994. These are commonly referred to as the Labour Side Agreement and The Environmental Side Agreement. See Government of Canada, North American Agreement on Labor Co-operation and North American Agreement on Environmental Co-operation Between the Government of Canada, the Government of the United Mexican States and the Government of the United States of America, Final Draft September 13, 1993. (Ottawa: Government of Canada, 1993).

- 1989 C.T.S. 3, H.R. Doc. No. 216, 100th Cong., 2d Sess. 297 (1988), cited by Appleton, supra note 1 at 3, 6n. See Appleton's comments (ibid. at 30) with respect to the transaction value method.

95 U.N.T.S. 194, GATT, BISD, 1st Sup. 6 (1953) cited by Appleton, ibid. at 3, 5n. See Appleton's comments (ibid. at 47 ) with respect to agricultural trade. 
Each chapter begins with a general introduction pertaining to the corresponding subject matter canvassed by the Treaty. If Appleton revises the book, I would suggest that this aspect of the text be expanded greatly. The book needs more of the analysis he provides briefly at the commencement of each chapter: the reader's appetite is whetted but never satisfied for this kind of explanation. The result is that the book is difficult to read in places, as the subject matter is not inherently fascinating when approached on a chapter-by-chapter basis. The book also suffers from a lack of discussion of issues from a Mexican perspective; this, however, is common to virtually all Canadian and American publications on this topic. This is due to a lack of facility with Spanish on the part of Canadian and American commentators, as well as to a limited number of English-language Mexican publications on the Agreement. ${ }^{10}$

The book commences with a constitutional analysis of the method of bringing treaties into force in each of Canada, the United States and Mexico. This is followed by a brief discussion of the relationship between the NAFTA and other international agreements. Appleton discusses the difficulty with Canadian implementation of the Agreement, as it is still uncertain whether the provinces will enact implementing legislation." One possibility raised in this chapter which is not really explored is the possibility that the NAFTA is not consistent with Article XXIV of the GATT. ${ }^{12}$ Similar concerns have been expressed about the Treaty on European Union ${ }^{13}$ but do not seem to be the source of serious challenges to free trade zones.

The author then examines the tariff and market access concessions in the Agreement. He notes that the NAFTA was intended to enhance market access for goods produced and traded in North America. ${ }^{14}$ Some judgment by Appleton as to whether the market access provisions are a significant change or improvement over the GATT obligations of each Party would be helpful. The discussion of tariff elimination and GATT national treatment ${ }^{15}$ raises the inference that these provisions create a dramatic change. We are told that tariffs will be eliminated over time with respect to various categories of goods. It is not clear what effect this will have on Canadians and whether the changes will be meaningful to consumers. Moreover, Appleton refers to categories A, B and C goods, ${ }^{16}$ but does not tell us what are categories A, B and C goods. Answers to these questions would assist those in a general practice in determining the relevance of the provisions in relation to their clients.

See e.g.: R. Ramirez, "The North American Free Trade Agreement from a Mexican Perspective" in S. Globerman \& M. Walker, eds., Assessing NAFTA: A Trinational Analysis (Vancouver: The Fraser Institute, 1993) at 60-86. The Mexico \& NAFTA Report, part of the Latin American Regional Report, published by Latin American Newsletters, London, England, is also useful.

Appleton, supra note 1 at 16-18.

Ibid. at 22.

13 Treaty on European Union (TEU), O.J. 1992 c. 191/1. This is commonly referred to as the Maastricht Treaty.

14 Appleton, supra note 1 at 23.

is Ibid. at 24-25.

$16 \quad$ lbid. at 25. 
Appleton then examines the rule of origin provisions in the NAFTA which stipulate that goods "originate" in North America that are produced or obtained entirely in North America. He notes that the method of assessing regional value content for goods in the NAFTA differs from that used in the Canada-U.S. Free Trade Agreement. ${ }^{17}$ As well, Appleton comments that the "yarn-forward" rule for textiles and apparel goods in the NAFTA is more stringent than the "double transformation test" required under the Canada-U.S. Free Trade Agreement. ${ }^{18}$ The significance of the provision is that "textile and apparel goods must be made from yarn produced by a NAFTA member country in order to be treated beneficially with regard to tariffs."

A key aspect of the Agreement from the perspective of Alberta practitioners are the provisions of the NAFTA pertaining to energy. Appleton observes that Canada and the United States are required to provide proportional access to energy or basic petrochemical goods to other parties during critical shortages. ${ }^{20}$ Limits are placed on the price that can be charged for the goods. He notes that "[t]he Mexican government avoided commitment on proportional sharing in the NAFTA."21 This is a key aspect of the Agreement for those practicing in the oil and gas industry.

Appleton contends in the chapter on investment that these provisions "constitute the very heart and soul of the NAFTA." ${ }^{22}$ The term "investment" is defined by a provision that tells us what the term does not mean, namely claims to money or the extension of credit for trade financing. ${ }^{23}$ The definition of investment is thus very broad and includes nearly all types of ownership interests including, for example, a business, debt securities, loans to business, real estate acquired for business purposes, and business interests that entitle the owner to share in the income or profits. ${ }^{24}$ Interestingly, although Appleton does not mention it, this provision was of some concern to the European Community as it was unhappy about the possible effect of this provision on its Members. The Community was concerned that the benefits of the NAFTA would only be enjoyed by companies that are:

majority owned/controlled by NAFTA nationals. This is contrary to Community practice towards foreign-owned firms established in the Community and in the European Economic Area and would constitute a very important and unjustified discrimination against Community owned/controlled subsidiaries in North America. ${ }^{25}$

Ibid. at 30.

Ibid. at 33-34.

L.A. Glick, Understanding the North American Free Trade Agreement: Legal and Business Consequences of NAFTA (Deventer: Kluwer Law and Taxation Publishers, 1993) at 21.

Appleton, supra note 1 at 41 .

Ibid. at 43.

lbid. at 79 .

Ibid. at 81 .

lbid. at 80-81. See NAFTA arts. 1138 and 1101 .

Commission of the European Communities, Information Note: North American Free Trade Agreement (NAFTA) (Brussels: COM (93) 188, 12 May 1993) at 15. 
In any event, the effect of the provisions in the investment chapter is to provide national treatment so that each party to the Agreement shall treat NAFTA investors, as well as their investments, no less favourably than its own investors and investors of other countries. ${ }^{26}$

In Appleton's view, the key to the entire agreement is found in the dispute settlement provisions. He asserts that: "[t]he introduction of a process which allows for widespread individual access to dispute resolution is perhaps the single most significant legal development which has taken place through the NAFTA."27

He contends that individuals will have the ability to shape the jurisprudence pertaining to the NAFTA to a larger extent than with respect to any other international agreement. Claims may only be brought by NAFTA nationals against governments for breach of obligations under the NAFTA Investment chapter. ${ }^{28}$ This is a major change from the usual provision that only states have standing in international legal disputes: "[a]n investor of a NAFTA Party who owns, or controls a company in another NAFTA Party may bring a claim regarding the breach of a NAFTA obligation." ${ }^{29}$

Interestingly, the Agreement also appears to permit NAFTA juridical nationals to invoke the Agreement against their own government indirectly where they would lack standing directly. Appleton cites the possibility of an American national who has invested in a Mexican corporation bringing a claim on behalf of the corporation against the Mexican government for breach of its investment obligations, in circumstances where a Mexican national would not have standing. ${ }^{30}$ The dispute is resolved by investor state tribunals composed of two arbitrators chosen by the litigants with a third appointed by agreement. ${ }^{31}$ The arbitral tribunals may only award damages, interest and restitution of property. They may not strike down provisions that violate the Agreement. ${ }^{32}$

Navigating NAFTA also includes an analysis of anti-dumping and countervailing duties. In my view, the analysis of this portion of the Agreement is excellent and is arguably the best part of the book. The Agreement creates binational panels to determine anti-dumping and countervailing duty disputes, rather than leaving this to domestic judicial review. ${ }^{33}$ The panels apply each party's particular standard of review because the Agreement does not create a harmonized set of trade laws for the three members. There is no obligation to harmonize anti-dumping and domestic subsidies in the NAFTA. This process started out as a temporary measure under the Canada-U.S. Free Trade Agreement and was supposed to be substituted with a common set of rules

Ibid. at 18 and Appleton, supra note $I$ at 82-83.

Appleton, ibid. at 149.

Ibid. at 149.

Ibid. at 150.

Ibid.

Ibid. at 152.

Ibid.

Ibid. at 136. 
for subsidies and anti-dumping duties. ${ }^{34}$ Authors have argued that the failure to create a harmonized system in the NAFTA is a serious flaw in the text of the Agreement. ${ }^{35}$ In any event, the current provisions are still important as they substitute binational panels for domestic judicial review. ${ }^{36}$

The author also canvasses the agriculture chapter, ${ }^{37}$ emergency action, ${ }^{38}$ technical standards ${ }^{39}$ and government procurement. ${ }^{40}$ My criticism of the procurement chapter is that the lengthy list of entities subject to these obligations is rather redundant. ${ }^{41}$

Appleton includes some useful graphics and lists for the reader. There is a helpful chart setting out the structure of the NAFTA Dispute-Settlement Process ${ }^{42}$ that helps make sense of somewhat Byzantine provisions. There is also a useful list of professionals who qualify under NAFTA chapter 16 for temporary entry in a NAFTA Party for business purposes. This permits individuals such as lawyers, pharmacists, engineers, dentists, nurses, post-secondary instructors, hotel managers and computer systems analysts to work temporarily in a NAFTA Party. ${ }^{43}$ This is particularly valuable information for those advising clients who wish to work in the United States without obtaining a Green Card.

The author also canvasses the Side Agreements on the Environment and Labour. ${ }^{44}$ The Side Agreements do not create harmonized laws in these important sectors but instead refer to a Party's failure to enforce its own domestic laws and regulations pertaining to a rather circumscribed list of matters. The dry tone of this chapter underlines the lack of teeth in the provisions made in these documents. For example, individuals lack standing under the dispute settlement provisions germane to labour and the environment. ${ }^{45}$ As well, the Parties may establish their own levels of domestic environmental protection and are not obliged to harmonize them upwards. ${ }^{46}$ Appleton can be criticized for brevity and a lack of insightfulness in this chapter. There is vast literature dealing with the issues of the environment and labour as they relate to the NAFTA which considers such matters as the desirability of creating meaningful penalties for failure to meet common standards. It is too early to tell how useful either of these texts will be to protecting labour or the environment. My own view is that they will be ineffectual.

Ibid. at 135-36.

See e.g. Glick, supra note 19 at 79-80.

Appleton, supra note 1 at 135 .

lbid. at $45-55$.

lbid. at 57-59.

lbid at 61-66.

Ibid. at 67-78.

lbid. at 71-78.

Ibid. at 133.

Ibid. at 119-21. The list includes over sixty different professions that qualify for such treatment. Ibid. at 173-88.

Ibid. at 178 .

Ibid. at 174 . 
The author contends finally that the NAFTA "displays a classical liberal noninterventionist view on what constitutes an appropriate role for government." ${ }^{47} \mathrm{I}$ would have liked to have seen this theme developed throughout the text of the book rather than in its final pages. He argues that the Agreement will restrict the ability of future governments to return to more protectionist economic policies, and that it limits "the scope of government activity in an attempt to create a level playing field." 48

Appleton cites some examples from the Agreement where efforts have been made to prevent the creation of trade restrictions in the future, through provisions that establish a dispute resolution system providing investors with adjudication of disputes against governments, restrictions on creating non-tariff barriers, and the obligation of government monopolies to follow only commercial considerations when dealing with delegated authority. However, arguably Appleton turns the usual concept of a level playing field in free trade areas on its head. For example, at the time the European Community was created, the French government insisted that provisions pertaining to social policy be included in the European Economic Community Treaty ${ }^{49}$ to guard against competitive disadvantage. France was concerned that countries whose policies were less generous with respect to employment law and benefits would obtain an unfair economic advantage. The French position was that it was essential to harmonize the costs of production to ensure that businesses competed on an equal basis throughout the Common Market once barriers to the free movement of persons and capital were eliminated. ${ }^{50}$ Various initiatives have been incorporated in Community law over time dealing with social policy which have created a sophisticated body of law encompassing harmonized standards that were adopted for economic reasons as well as for purposes of social justice. For example, increasingly, the Community (and now the European Union) has used social policy to better the position of labour. Looking at a "level playing field" from this perspective, Appleton's suggestion that the NAFTA provisions attempt to create such a field by limiting the scope of government activity is startling. I am of the view that what the "liberal non-interventionist view on what constitutes an appropriate role for government" ${ }^{51}$ created in the NAFTA was instead an uneven playing field. ${ }^{52}$ This may or may not be a good outcome. I would have liked to have seen Appleton, throughout the book, take a position on this matter. As well, against Appleton's view that future governments are hampered in their actions by the NAFTA, one might argue that given the fact that any Party may terminate their

Ibid. at 205.

lbid.

Treaty Establishing the European Economic Community, 25 March 1957, No. 4300, 298 U.N.T.S.3 [hereinafter EEC Treaty]. There are other Community Treaties, namely the Treaty Establishing the European Coal and Steel Community, 18 April 1951, reported in Treaties Establishing The European Communities (Luxembourg: Office for Official Publications of the European Communities, 1987) at 23; the Treaty Establishing the European Atomic Energy Community, 25 March 1957, 298 U.N.T.S. 167; and the Treaty on European Union, supra note 13.

E. Ellis, European Community Sex Equality Law (New York: Oxford University Press, 1991) at 38.

Appleton, supra note 1 at 205.

For commentary on the impact of the NAFTA, see e.g. J. Lemco \& W.P. Robson, eds., Ties Beyond Trade: Labour and Environmental Issues Under the Nafia (Toronto: C.D. Howe Institute, 1993); and Globerman \& Walker, eds., supra note 10. 
participation in the Agreement on six months notice, it does not appear that future governments will be unduly hampered in this regard. ${ }^{33}$ Of course, terminating the Agreement is an all or nothing approach which may not be palatable to a Party.

I would recommend this book for an entry-level course in the NAFTA or for those wanting a general overview of the Agreement. In future editions I would urge Appleton to engage in greater analysis, such as that found in the dispute settlement chapter ${ }^{54}$ and the chapter which discusses frequently raised concerns on the NAFTA. ${ }^{55}$ His desire for objectivity and lack of bias makes the book rather dry. From time to time, he gives us small insights about controversial aspects of the Agreement, but for the most part he never really delves into the various arguments to be made for and against particular provisions. An examination of traps for the unwary and useful tips for the novice international trade lawyer advising clients in this area would be useful. Notwithstanding these problems, the book is well written and accurate. He aims to provide an accessible, objective explanation of the text of the Agreement, and he succeeds in that regard.

Ellen E. Hodgson, B.A., LL.B., LL.M. Executive Assistant to the Chief Justice Court of Appeal of Alberta 